\title{
Evaluation of Dominant Physical Ability in Dispora Fostered Athletes in Aceh Province Athletic Branch in
}

\author{
Nasriah \\ Study Program Physical Education and Recreation Health, Faculty of Teacher Training and Education (FKIP), \\ Syiah Kuala University \\ *Corresponding author. Email: riahnas68@yahoo.com
}

\begin{abstract}
Evaluation of Dominant Physical Ability in DISPORA Fostered Athletes in Aceh Province Athletic Branch in 2013Physical condition is a unified whole of components that cannot be separated, either improvement or maintenance, athletics is the oldest sport or is said to be the mother of other sports, in which there are some basic movements that are classified as complete. Based on observations it can be illustrated that there is still a lack of seriousness in the athletes doing physical condition exercises from Monday to Saturday, held every morning and evening. This study aims to determine the dominant physical abilities of athletes under the auspices of DISPORA Aceh Province in athletics. The type of research used is descriptive research. The population in this study were all athletes assisted by DISPORA in Aceh Province with 14 athletes, considering the relatively small population, all populations were sampled using a total sampling technique. Data collection techniques were carried out by: dominant physical condition tests namely endurance, power, strength, speed, and flexibility tests consisting of 10 test items, namely: (1) vartical jump test 1 minute, (2) 1 minute push up test, (3) 1 minute sits up test, (4) 1 minute squat jump test, (5) right and left arm hand dynamometer test, (6) dynamometer lag test, (7) medicine ball push test, (8) sit end test reach, (9) run test of 50 meters, (10) run test of 2,400 meters. Data processing is done using statistical formulas in the form of calculating the average value (mean), and percentage. The average results obtained in the physical condition research are as follows: (1) the vartical jump test $\left((X)^{-}=41.5\right)$ is categorized sufficiently while in the category of a good daughter (2) push up test $\left((\mathrm{X})^{-}=39,64\right)$, categorized as perfect, (3) sits up test $\left((\mathrm{X})^{-}=64.85\right)$ categorized well while in the category of perfect daughter, (4) squat jump test $\left((X)^{-}=72\right)$ very well categorized while in the perfect daughter category, (5) the right arm hand dynamometer test $((X) 56=56.65)$ was perfectly categorized, (6) the left arm hand dynamometer test $((X) 35=35.84)$ was categorized well while in the perfect daughter category , (7) lag dynamometer test $((\mathrm{X}) 136=136.45)$ is well categorized, (8) medicine ball push test $((\mathrm{X}) 4,=4.47)$ is categorized very well, $(9)$ sit end reach flexibility test $\left((X)^{-}=21.91\right)$ was categorized very well, $(10)$ the 50 meter running test $((\mathrm{X}) 8,=8.21)$ was lacking while in the female category was good, while $(11)$ the 2,400 meter running test $\left((\mathrm{X})^{-}=8.71\right)$ is categorized as good li. It can be concluded that the physical condition is dominant in the DISPORA Fostered Athletes of the Aceh Province Athletic Branch in 2013 in the good category.
\end{abstract}

Keywords: Evaluation of Dominant Physical Ability in Dispora Fostered Athletes

\section{INTRODUCTION}

Athletics is the oldest sport or is said to be the sports mom of other sports. Athletics is a physical activity that competes on various numbers of roads, running, jumping and throwing. Each of these numbers requires training in good physical condition to improve skills, strength, stamina, circulation system and heart work in order to achieve maximum performance. This is consistent with Jarver's statement. A (1986: 9) Whereas: Each branch of sport demands certain physical and emotional conditions for the achievement of champion level performance. Therefore, physical condition is a very important role for athletes from various sports to run a game smoothly and optimally. As the statement of Harsono (1988: 153) Good physical conditions can affect several systems of the body's organism that can improve the ability of the circulatory system and the work of the heart, can increase strength, flexibility, stamina and other physical condition components, there will be better anatomic motion in during exercise, there will be a faster recovery in the organs of the body after 
exercise, and there will be a quick response from our body's organisms if at any time the response is needed.

Not only physical conditions are needed but support from good techniques, tactics, mentality and the environment. Good physical condition can be obtained by frequently doing continuous exercises every day by increasing the burden is increasing day by day, in order to increase endurance and freshness in the body. Jarver further. A. (1986: 14) That: Exercise physical condition is one of the most important parts for all exercises in the field / branch of sport.

The goal is to establish the condition of the body as a basis for increasing endurance and freshness in the body. Factors that can support the efficacy of various types of sports are physical or good physical condition components, namely endurance, explosive power, flexibility, speed, agility, accuracy, strength, balance, coordination, and reaction. This component is an element of basic physical abilities that must be developed in sports. Physical condition training is the most basic rule that affects every branch of sport, because good physical condition training is the basis for increasing endurance and freshness in the athlete's body.

This is consistent with Anwar's statement (2006: 200) that: Athletes who carry out intensive physical condition training programs for 6-10 weeks will have better strength, endurance and stamina. Therefore, this physical ability is very much needed when an athlete has to perform in a competition. Generally this physical condition training is programmed in such a way that it is far more difficult and difficult than what is needed when competing. The most dominant physical condition components in Athletics are found in all numbers are endurance, strength, power, speed, and flexibility. This is consistent with the statement: Nurhasan (1992: 235) That: Endurance, strength, power, speed, and flexibility. To obtain success and technical skills need to be considered so that someone is proficient in doing the whole movement in a branch of the sport.

The above statement explains that the components of physical condition are very important in achievement. Physical condition is also considered important because it can maintain or improve one's physical fitness, the physical fitness of an athlete determines his physical abilities when carrying out daily tasks or activities. The higher the degree of physical fitness of an athlete the higher the ability of physical work and the less likely to avoid injury.Cabang olahraga Atletik adalah cabang olahraga tertua atau dikatakan ibu

One of the mentoring and supervision of the Aceh Province Youth and Sports Agency is the Center for Student Training and Sports Training (PPLP). PPLP is a discourse that has been formed through discussions from various parties / sports experts such as the education office, youth and sports services, KONI, youth and sports agencies throughout Indonesia, organized by deputies in the field of performance improvement and sports science and technology and the state ministry of youth and sports. In this PPLP there are athletes who excel who have participated in various selections to be included in the PPLP.

The achievements of DISPORA Athletes under the Aceh Province from year to year can not be predicted, the graphs sometimes go up or down, this is evident in the participation of athletes and the achievements that are obtained each year, such as the championships between PPLP in Surabaya in 2004, the Provincial PPLP team Aceh Achieved 1 golden throwing disc. But in 2005, the PPLP Aceh Province was given bronze, silver in the discus throwing number, then in the POPNAS the field received gold in the high jump number. In 2006 to Jakarta JOURNAL, he got 1 bronze and among PPLP in Papua he got 1 gold in the high jump number. In 2007, he won 1 gold between PPLP in Jakarta and a JURNAS junior gold student in Asia. In 2008, PON in East Kalimantan won 1 gold in the high jump number. In 2009 received 1 bronze and 1 gold in the number of javelin and high jump, then in 2010 in the distance between PPLP long jump received 1 gold. In 2011, PPLP in Riau received 1 silver and 2 silver POPNAS. Whereas in 2012 the DISPORA fostered athletes in Aceh Province did not get the champion.

Then the problem arises from the researchers wanting to see and assess the extent of physical abilities in athletes fostered by DISPORA Aceh Province. Physical condition is a very important role in every branch of sport, because physical condition is very necessary to improve athlete's achievement so that in the future they will continue to excel. These physical condition activities or exercises are often carried out by DISPORA-trained Athletes of Aceh Province, the nation's hope stadium. The exercises are usually carried out from Monday to Saturday from 03 to 04 WIB. The physical condition exercises carried out are inseparable from the guidance of experienced pelati.

An athlete certainly has an advantage over ordinary people or students, the advantage of these athletes is that athletes are never separated from the training programs that have been arranged by the coach, they do training every day to improve the achievements to be achieved in the future. Athletic sports are strongly influenced by good physical conditions, the reason researchers want to know how much the role or dominant physical abilities in the athletes fostered DISPORA Aceh Province Athletics branch. Physical ability in athletics is one of the training programs established or arranged in such a way by coaches who 
must be trained and participated in by all DISPORA Aceh-trained Athletes.

\section{METHODS}

This research includes descriptive research or evaluation research. This is in accordance with Pohan's statement. R. (2007: 6) Descriptive research is research on the facts that exist today and report them as what happened. As for the population in this study were all of the DISPORA Fostered Athletes in Aceh Province in 2013 which consisted of 14 athletes. While the sample is the smallest part of the population or representative of the population. So the reason researchers took all populations as a sample is based on the number of populations that are small populations or less than 30 people and are small populations. The sampling technique used is total sampling.

Table.1 Population Conditions and Samples of DISPORA-assisted Aceh Province Aceh Athletic Branches in 2013

\begin{tabular}{|c|c|c|c|c|c|}
\hline No & Name & Number & Gender & Age & Ket \\
\hline 1 & $\begin{array}{l}\text { Riska Mullia } \\
\text { Nanda }\end{array}$ & Outbreak & Women & 17 year & \\
\hline 2 & $\begin{array}{l}\text { Frilliyanti } \\
\text { Chairannisa }\end{array}$ & Long jump & Women & 17 year & \\
\hline 3 & $\begin{array}{l}\text { Iswanda } \\
\text { Surya N }\end{array}$ & $\begin{array}{c}\text { Run } 100 / 200 \\
\text { Meter }\end{array}$ & Men & 18 year & \\
\hline 4 & $\begin{array}{l}\text { Faud } \\
\text { Ramadhan }\end{array}$ & $\begin{array}{c}\text { Run } 100 / 200 \\
\text { Meter }\end{array}$ & Men & 18 year & \\
\hline 5 & Sartinah & Run 800 Meter & Women & 16 year & \\
\hline 6 & M. Tarik & $\begin{array}{c}\text { Run } 100 / 200 \\
\text { Meter }\end{array}$ & Men & 17 year & \\
\hline 7 & Afrurazi & Run 400 Meter & Men & 17 year & \\
\hline 8 & Subki & Run 400 Meter & Men & 17 year & \\
\hline 9 & Rama Akbar & Javelin & Men & 16 year & \\
\hline 10 & $\begin{array}{l}\text { Muhammad } \\
\text { Ardial }\end{array}$ & Javelin & Men & 18 year & \\
\hline 11 & Multhazam & Javelin & Men & 17 year & \\
\hline 12 & Mirza & Discus throw & Men & 16 year & \\
\hline 13 & $\begin{array}{l}\text { Riski } \\
\text { Iwantona }\end{array}$ & Javelin & Men & 17 year & \\
\hline 14 & $\begin{array}{l}\text { Febri } \\
\text { Muhammad } \\
\text { Sani }\end{array}$ & Discus throw & Men & 17 year & \\
\hline
\end{tabular}
Province

Source: DISPORA Athletics Trainer Aceh

The process of data collection and data collection in this study used a test of the dominant physical conditions found in athletics, including endurance, strength, power, speed and flexibility. As for the tests of the dominant physical condition, there were 10 (ten) test items in accordance with the establishment of Nurhasan (1992: 222) namely: measurement of leg muscle power using Friday verticle test, measurement of local endurance of arm muscle using push up test, measurement of endurance of abdominal muscles using test sits up, measurement of leg muscle endurance using squat jump test, measurement of arm muscle strength using a hand dynamometer test, measuring leg muscle strength using a leg dynamometer test, measuring arm and shoulder muscle power using a medicine ball push test, measuring Flexibility using the Flexometer test (sitting up and reaching), measuring the speed using a 50 meter running test, measuring heart endurance lung using a 2,400 meter running test.

Analysis of the data used is to calculate the average value, Sudjana (2001:67)

$$
\bar{X}=\frac{2 X}{n}
$$

Ket:

$\bar{x}=$ The calculated average value

$\sum=$ Epsilon (baca jumlah)

$x_{\mathrm{i}}=$ The sum of all existing $\mathrm{x}$ prices

$\mathrm{N}=$ Number of Samples

Analysis to look for Percentage, Sudjana

(2001:67)

$$
\begin{aligned}
& P=\frac{F}{N} x 100 \% \\
& \text { Ket: } \\
& \mathrm{P}=\text { Persentase } \\
& \mathrm{f}=\text { frekuensi } \\
& \mathrm{N}=\text { Number of Samples } \\
& 100 \%=\text { Fixed number }
\end{aligned}
$$

\section{RESULT AND DISCUSSION}

\section{A. Result}

Based on the results of research and data processing of the dominant physical ability tests for athletes under the auspices of DISPORAS Aceh Province athletic branches in 2013, which consisted of 10 test items the following results were obtained.

a. Leg muscle power (vartical jump) arising from efforts to improve and foster physical condition and achievements of athletes in athletic sports are in the excellent category $(7.10 \%)$, good $(28.50 \%)$, sufficient $(28.50 \%)$, less $(35.70 \%)$, with a very good frequency of 1 person, good 4 people, enough 4 people, and less 5 people.

b. The endurance of the arm muscles (push up) arising from the efforts to improve and foster physical condition and the achievements of athletes in athletic sports are in the perfect category $(50 \%)$, very good $(50 \%)$, with a frequency of perfect 7 people, and very good 7 person.

c. Endurance of abdominal muscles (sits up) arising from efforts to improve and foster physical condition and achievements of athletes in athletic sports are in the perfect category $(21.40 \%)$, very good $(28.50 \%)$, good $(21.40 \%)$, enough $(28.50 \%)$, 
with a perfect frequency of 3 people, very good 4 people, good 3 people and enough 4 people.

d. Endurance of leg muscles (squat jump) arising from efforts to improve and foster physical condition and achievements of athletes in athletic sports are in the perfect category $(21.40 \%)$, very good $(21.40 \%)$, good $(50 \%)$, enough $(7.10 \%)$, with a perfect frequency of 3 people, very good 3 people, good 7 people and enough 1 person.

e. The muscle strength of the right arm (hand dynamometer) caused by the efforts to improve and develop physical condition and the achievements of athletes in athletic sports are in the perfect category $(21.40 \%)$, very good $(50 \%)$, good $(7.10 \%)$, enough $(7.10 \%)$, less $(14.20 \%)$ with a perfect frequency of 3 people, very good 7 people, good 1 person, enough 1 person, and less 2 people.

f. The muscle strength of the left arm (hand dynamometer) caused by the efforts to improve and develop physical condition and the achievements of athletes in athletic sports are in the excellent category $(14.20 \%)$, good $(42.80 \%)$, sufficient $(21.40 \%)$, less $(21.40 \%)$ with a very good frequency of 2 people, good 6 people, enough 3 people, and less 3 people.

g. Lag dynamometer which is caused by the improvement and development of physical conditions and the achievements of athletes in athletic sports are in the excellent category (14.20\%), good $(28.50 \%)$, sufficient $(57.10 \%)$, with an excellent frequency of 2 people, good 4 people, and enough 8 .

h. Arm and shoulder muscle power (medicine ball push) arising from efforts to improve and foster physical condition and achievements of athletes in athletic sports are in the good category $(35.70 \%)$, sufficient $(35.70 \%)$, less $(28.50) \%$ ), with a good frequency of 5 people, only 5 people and less 4 people.

i. Determination (sit and reach) arising from efforts to improve and foster physical condition and achievements of athletes in athletic sports are in the perfect category $(21.40 \%)$, very good $(28.50 \%)$, good $(50 \%)$, with frequency perfect 3 people, very good 4 people and good 7 people.

j. The speed (running 50 meters) caused by the efforts to improve and develop physical condition and the achievements of athletes in athletic sports are in the perfect category $(7.10 \%)$, very good $(7.10 \%)$, good $(7.10 \%)$, enough $(78.50 \%)$, with a perfect frequency of 1 person, very good 1 person, good 1 person and enough 11 people. k. Cardiovascular endurance (running 2,400 meters) caused by efforts to improve and develop physical condition and the achievements of athletes in athletic sports are in the excellent category $(35.70 \%)$, good $(42.80 \%)$, moderate $(21.40 \%)$, with a very good frequency of 5 people, good 6 people and 3 people

\section{B. Discussion}

Based on the results of research and data processing of the dominant physical abilities test in the DISPORA Assisted Athlete of the Aceh Province Athletics Branch in 2013, which consisted of 10 test items. So the average results obtained from the vartical Jump test is 41.5 which based on the norm table is in the sufficient category while in the norm table the daughter is in the good category. Push Up Test the average results obtained from the push up test is 39.64 which based on the norm table is in the perfect category. Sits Up Test The average results obtained from the sits up test are 64.85 which based on the norm table is in the good category while in the norm table the daughter is in the perfect category. Squat Jump test the average results obtained from the squat jump test is 72 which based on the norm table is in excellent category while in the norm table the daughter is in perfect category.

Right Arm Hand Dynamometer Test The average results obtained from the right arm hand dynamometer test were 56.65 based on the norm table in the perfect category. Left hand arm dynamometer test the average results obtained from the hand arm left hand dynamometer test was 35.84 which based on the norm table is in good category while in the norm table the daughter is in perfect category. Lag Dynamometer test the average results obtained from the lag dynamometer test was 136.45 which based on the norm table is in the good category. Medicine Ball Push Test The average results obtained from the medicine ball push test is 4.47 which based on the norm table is in the good category while in the norm table the daughter is in the excellent category.

Flexibility Test The average results obtained from the Flexibility Test are 21.91 which based on the norm table is in the excellent category. 50-meter Running Test The average results obtained from the 50meter running test is 8.21 which based on the norm table is in the poor category while in the norm table the daughter is in the good category. Running Test of 2,400 Meters The average results obtained from the Running Test of 2,400 meters is 8.71 which based on the norm table is in the excellent category while in the women's norm table is in the perfect category. So from the results of the research and data processing above, it can be concluded that the level of ability of the dominant physical condition in the DISPORA Fostered Athletes 
of the Aceh Province Athletic Branch in 2013 is in the Good category.

\section{CONCLUSION}

The average results obtained in the physical condition research are as follows: (1) the vartical jump test $\left((X)^{-}=41.5\right)$ is categorized sufficiently while in the category of a good daughter (2) push up test $\left((\mathrm{X})^{-}=39\right.$, $64)$, categorized as perfect, (3) sits up test $\left((X)^{-}=64.85\right)$ categorized well while in the category of perfect daughter, (4) squat jump test $\left((X)^{-}=72\right)$ very well categorized while in the perfect daughter category, (5) the right arm hand dynamometer test $((X) 56=56.65)$ was perfectly categorized, (6) the left arm hand dynamometer test $((X) 35=35.84)$ was categorized well while in the perfect daughter category , (7) lag dynamometer test $((\mathrm{X}) \quad 136=136.45)$ is well categorized, (8) medicine ball push test $((\mathrm{X}) 4,=4.47)$ is categorized very well, (9) sit end reach flexibility test ( $\left.(X)^{-}=21.91\right)$ was categorized very well, (10) the 50 meter running test $((\mathrm{X}) 8,=8.21)$ was lacking while in the female category was good, while (11) the 2,400 meter running test $\left((\mathrm{X})^{-}=8.71\right)$ is categorized as good li.

\section{REFERENCES}

[1] Arikunto, S. 2002. Prosedur Penelitian. Cet. Ke12. Rineka Cipta: Jakarta.

[2] Arikunto. S. 2010. Prosedur Penelitian. Cet. Ke 14. Jakarta: Rineka Cipta

[3] Ahmadi, N. 2009. Panduan Olahraga. Surakarta: Era Pustaka Utama.

[4] Anwar Dasril. 2006. Pedoman Parameter Tes dan Penyusunan Program Latihan Pembinaan Prestasi Olahraga. Jakarta.

[5] Harsono.1988. Coaching dan Aspek-Aspek Psikologi dalam Coaching. CV Tambak Kusuma. Jakarta.
[6] Hairy Junusul.2007. Dasar-Dasar Kesehatan Olahraga. Universitas Terbuka. Jakarta

[7] Jarver. A. 1986. Belajar dan Berlatih Atletik. Pionir Jaya. Bandung.

[8] Kamus Besar Bahasa Indonesia. 2005. PT Gramedia Pustaka.Jakarta.

[9] Mutohir. C.T dan Maksum.A. 2007. Sport Development Index. Cetakan pertama. PT. Index: Jakarta.

[10] Nurhasan, R. dkk. 1992. Manusia dan Olahraga. ITB: Bandung.

[11] Nadisah, R. dkk. 1992. Manusia dan Olahraga. ITB: Bandung.

[12] Pohan. R. dkk. 2007. Metodelogi Penelitian. Dahara prizi: Semarang.

[13] Sudjana. 2001. Metode stastika. Tasito. Bandung.

[14] Setiawan. R. dkk. 1992. Manusia dan Olahraga. Bandung: ITB

[15] Sajoto. 1988. Peningkatan dan Pembinaan Kekuatan Kondisi Fisik dalam Olahraga, Dahara Prize: Jakatra

[16] Suherman. A. dkk. 2001. Pembelajaran Atletik Pendekatan Permainan dan Kompetisi. Direktorat Jendral Olahraga. Jakarta.

[17] Udang-Undang No 3 Tahun 2005. Sistem Keolahragaan Nasional

[18] Wahjoedi. 2001. Landasan Evaluasi Pendidikan Jasmani. PT Raja Grafindo Persada: Jakarta.

[19] Wirawan.2011.Evalauasi Tiori, Model, Standar, Aplikasi, dan Profesi. PT. Raja Grafindo Persada: Jakarta.

[20] Zainuddin. 2010. Rumus dan Data dalam Aplikasi Statistik. Cet. Ke-4. Alfabeta: Bandung. 